Jurnal Interpretasi Hukum |ISSN: 2746-5047

Vol. 2, No. 2 - Agustus 2021, Hal.372-377 | Tersedia online di https://www.ejournal.warmadewa.ac.id/index.php/juinhum DOI : https://doi.org/10.22225/juinhum.2.2.3443.372-377

\title{
PERTANGgungJaWABAN PIDANA PELAKU CYBER CRIME DENGAN KONTEN PORNOGAFI
}

\author{
I Kadek Arya Sumadiyasa, I Nyoman Gede Sugiartha \& I Made Minggu Widyantara \\ Fakultas Hukum Universitas Warmadewa, Denpasar-Bali, Indonesia \\ asumadiyasa@gmail.com, nyomansugiartha14@gmail.com, mademinggu21@gmail.com
}

\begin{abstract}
Abstrak
Era globalisasi telah membawa perubahan dan kemajuan yang cepat dalam kehidupan tanpa batasan jarak dan waktu. Kemajuan juga telah menimbulkan keresahan baru dengan munculnya kejahatan yang canggih dalam bentuk cybercrime, salah satunya yaitu penyebaran konten pornografi melalui sarana internet yang masuk kedalam cybercrime yang merupakan kejahatan dengan menggunakan teknologi informasi. Penelitian ini bertujuan untuk mengkaji bentuk pengaturan hukum terhadap pelaku tindak pidana penyebaran konten pornografi melalui sarana internet yang di kualifikasikan sebagai cybercrime dan membahas mengenai pertanggungjawaban pidana terhadap pelaku tindak pidana penyebaran konten Pornografi melalui sarana internet yang di kualifikasikan sebagai cybercrime. Metode yang digunakan adalah metode normatif, dengan menggunakan pendekatan perundang-undangan dan pendekatan konseptual. Hasil penelitian ini menunjukkan bahwa Pertanggungjawaban pidana pelaku cybercrime penyebar konten pornografi dapat ditinjau pada Pasal 282 KUHP dan Pasal 27 ayat (1) UU ITE, serta Pasal 4 UU Pornografi. Serta upaya penanggulangannya dilakukan dengan upaya preventif dan represif. Diharapkan nantinya pengaturan yang saat ini berlaku dapat memberika efek jera serta meminimalisir terjadinya penyebaran konten pornografi dengan kualifikasi cybercrime.
\end{abstract}

Kata kunci: Cybercrime, Konten Pornografi, Pertanggungjawaban pidana.

\begin{abstract}
The era of globalization brings rapid changes in life without limitations. Progress has also given rise to new concerns about cybercrime, one of which is the spread of pornographic content via the internet into cybercrime, which is a crime using information technology. This research aims to analyze the form of legal arrangements for the perpetrators of the distribution of pornographic content through the internet which is qualified as cybercrime and discuss criminal liability for the perpetrators of the distribution of pornographic content through the internet which qualifies as cybercrime. The method used is the normative method with statutory approach. The criminal responsibility for cybercrime perpetrators who spread pornographic content can be Article 282 of the Criminal Code and Article 27 paragraph (1) of the ITE Law, as well as Article 4 of the Pornography Law. As well as countermeasures with preventive and repressive measures. It is hoped that later the applicable regulations can provide a deterrent effect and minimize the occurrence of cybercrime.
\end{abstract}

Keywords: Criminal liability, cybercrime, content pornography.

\section{PENDAHULUAN}

Pada zaman modern seperti sekarang segala sesuatu dapat dilakukan dari rumah ataupun dari mana saja dengan bermodalkan telepon genggam atau alat yang dapat mengankses intenet seperti jam tangan pintar dan laptop yang makin kesini makin banyak varian dan jenisnya. Kemudahan tersebut berdampak positif dan negatif yang mana segala sesuatu di permudah dengan konsekuensi tidak terkecuali hal negatif pun menjadi mudah dan melahirkan jenis kejahatan baru seiring berkembangnya zaman dan yang sangat dekat serta sering menjadi perdebatan yaitu konten pornografi di internet temasuk media sosial saat ini.

Dari dampak mudahnya menyebarkan konten berunsur pornografi di intenet mengakibatkan mudah nya di akses oleh halayak luas sehingga bagi mereka yang menyebarkan konten pornografi di internet diatur dalam KUHP pada pasal 282 serta pada UU ITE Pasal 27 
ayat (1) dan mengkerucut ke ke pengaturan pada UU Pornografi Pasal 4 ayat (1) dengan sanksi yang sangat jelas tercantum pada ketentuan pasal nya tapi di dalam praktek pertanggungjawaban pidana nya terhadap pelaku masih belum cukup tegas karena semakin kesini untuk mengakses konten pornografi atau pun orang yang membuat semakin banyak dan semakin mudah pada proses penyebarannya.

Akibat dari banyaknya dan mudahnya konten pornografi berkeliaran di dunia maya tanpa ada tindakan tegas dari aparat hukum sehingga menimbulkan banyak korban yang terdampak dari pelaku yang menyebarkan konten maupun pelaku yang berefek dari hasil menonton konten ponografi yang bisa dibilang kurang batasan atau saringan umur untuk mengakases internet yang positif dan bermanfaat bagi masyarakat dan generasi penerus bangsa. Hal ini terbukti didalam penelitian Geni, et al (2020) bahwa anak dibawah umur tidak luput dari konten pornografi ini, di mana anak dijadikan objek dalam konten pornografi tersebut. Dalam penelitiannya geni et al, menjelaskan bahwa pelaku pornografi dapat dijerat dengan Pasal 27 ayat (1) UU ITE, Pasal 4 ayat (1) Undang-Undang Nomor 44 Tahun 2008 tentang Pornografi, dan Pasal 52 UU ITE. Sedangkan dalam penelitian, (Nadia \& Mahfud, 2018) mengkaji pertanggungjawaban pidana terhadap pelaku penyalahgunaan aplikasi streaming "Bigo Live" dalam konten pornografi. Penelitian terakhir membahas kebijakan hukum pidana dalam penanggulangan tindak pidana cybercrime di bidang kesusilaan (Djanggih, 2013).

Berdasarkan penjelasan di atas, peneliti memutuskan untuk mengkaji pertanggung jawaban pidana pelaku cybercrime dengan konten pornografi. Penelitian ini bertujuan untuk mengkaji bentuk pengaturan hukum terhadap pelaku tindak pidana penyebaran konten pornografi melalui sarana internet yang di kualifikasikan sebagai cybercrime dan membahas mengenai pertanggungjawaban pidana terhadap pelaku tindak pidana penyebaran konten Pornografi melalui sarana internet yang di kualifikasikan sebagai cybercrime.

\section{METODE PENELITIAN}

Penelitian yang dipergunakan dalam penelitian skripsi ini adalah jenis normatif yang menjadikan norma hukum sebagai objek dan pendekatan masalah dengan mengkaji sumber kepustakaan dan konseptual norma yang sudah ada (Atmadja \& Budiartha, 2018). Bahan Hukum Primer Bahan yang menggunakan bahan hukum primer berpedoman terhadap peraturan perundang-undangan dan keputusan yang inkrah. Bahan Hukum Sekunder, Bahan hukum yang dipeoleh dari jurnal hukum, buku hukum, serta internet yang memuat penyebaran konten pornografi dalam perspektif hukum positif di Indonesia. Bahan Hukum Tersier, Diperoleh berdasarkan pada kamus hukum serta ensiklopedia yang berkaitan dengan informasi hukum. Teknik Pengumpulan Bahan Hukum Hal ini dilakukan dengan cara mencatat, mengutip, membaca, maupun meringkas literatur yang mengacu terhadap perubahan status jenis kelamin di indonesia. Menganalisis setiap bahan buku yang dipergunakan untuk memilih yang sesuai dengan topik dari penelitian skripsi yang mana akan di analisis dengan sistematis dan mengaitkannya dengan bahan hukum lainnya.

\section{HASIL DAN PEMBAHASAN}

\section{Ketentuan Pengaturan Hukum Tindak Pidana Penyebaran Konten Ponografi Sebagai Cyber Crime}

Tinjauan umum tentang konten pornografi dari berbagai aspek kajian pustaka pornografi menurut black's law dictionary yang di tulis ulang Adami Chazawi yang dengan berjudul "Tindak Pidana Pornografi", "istilah pornografi berasal dari dua suku kata Pornos dan Grafi dalam Bahasa latin. Pornos berarti suatu tindakan asusila atau cabul atau tidak senonoh. Kemudian grafi merupakan tulisan atau gambar, dengan luasan arti masuk ke dalam benda, misalnya patung serta alat untuk mencegah dan menngugurkan kehamilan (Chazawi, 2016). Sedangkan menurut Undang-Undang RI No. 19 tahun 2016 tentang Informasi dan Transaksi Elektronik khususnya pada pasal 27 ayat (1) tidak menyebutkan apa itu pornografi akan tetapi pada pasal 27 ayat (1) menegaskan "hal-hal yang melanggar kesusilaan". Terdapat ketekaitan 
penjelasan pornografi pada pasal 1 UU Ponografi dan pasal 27 ayat (1) UU ITE yaitu dalam poin "melanggar kesusilaan".

Dasar dari kutipan diatas menyimpulkan ponografi bermakna dari UU pornografi memiliki jangkauan luas mengacu dan di bandingkan dengan pasal 27 ayat (1) UU ITE serta KUHP. Dapat di lihat dari pandangan Indra Safitri dalam pengambilan di buku Maskun yang berjudul "Kejahatan siber cybercrime", indra safitri berpendapat bahwa suatu tindakan jahat dengan teknologi terikat erat dengan suatu teknologi digital tanpa batasan, serta bekarakter sebuah yang kuat adanya manipulasi super canggih dalam perkembangan yang pelaku lakukan (Maskun, 2013 : 47). Sejalan dengan penjalasan tersebut maka peneliti berpendapat cybercrime adalah kejahatan menentang hukum yang menggunakan kecanggihan teknologi tinggi dengan suatu peralatan atau sarana.

Kejahatan dengan tujuan kesusilaan ada dua kejahatan terhadap kesopanan dan serta kesusilaan dan berada diluar kesusilaan, seperti kejahatan melanggar kesusilaan umum dan kejahatan pornografi. Hal jahat ini diatur dalam KUHP pasal 281-299 dan 301, 504, 505, serta pada pasal 532-547. Hal ini menunjukan bahwa tindakan kejahatan kesusilaan merupakan suatu bentuk pelanggaran norma-norma hukum, agama, dan sosial. Menurut sudut pandang Sianturi dengan Djoko Prakoso Sianturi, keduanya berpendapat suatu tindakan asusila yang jahat erat kaitanya dengan prilaku dan sifat dalam permasalahan pola pikir seksual dan saling terkait sehingga menjadi kejahatan asusila (Mudzakkir, 2010: 12). Pada kenyataannya undang - undang ternyata kurang menjelaskan tentang pelanggaran tindakan asusila, mengenai perbutatan akan tindakan dari seseorang yang secara sadar menyebarluaskan suatu konten yang berisikan kesusilaan oleh pembentuk UU telah diatur dalam KUHP yakni di pasal 282 ayat (1).

Namun dalam proses berkembangnya pengaturan serta penegakan hukum terkait penyebaran konten pornografi sebagai cybercrime pada KUHP lebih luas atau undang - undang terkait seperti UU Tentang Pornografi dan/atau UU ITE lebih kompleks di bandingkan dengan KUHP. Dan berdasarkan UU Pornografi Pada dasarnya, pengaturan tindak pidana pornografi bukan suatu masalah yang baru, sebab tindak pidana pornografi bukan hanya diatur dalam undang-undang No. 44 Tahun 2008 Tentang Pornografi, namun terlebih dahulu pornografi diatur dalam Kitab Undang - Undang Hukum Pidana (KUHP), Dalam KUHPidana, termuat dalam Pasal 282-283, Pasal 532 dan Pasal 533 KUHPidana (Wirawan, 2013).

Pengaturan secara menyendiri tentang Pornorafi di Indonesia yaitu pada UU No. 44 Tahun 2008 Tentang Pornografi, dan tentang pornografi termuat didalam UU Pornografi ketentuan pasal 29 - 38. Undang-Undang ini menetapkan secara tegas bentuk hukuman dari pelanggaran tindakan menyebarluaskan, dan pemakaian pornografi yang sesuai dengan tingkat pelanggaran yang dilakukan. Selain itu pemberatan dapat diberikan kepada pelaku yang dilakukan oleh korporasi dengan melipat gandakan pemberian hukuman tambahan dan sanksi pokok.

Penggunaan media komunikasi internet sebagai media untuk melakukan kejahatan memilki klasifikasi yang berbeda dengan kejahatan konvensional lainnya. Dalam proses bernegara aturan terkait telekomunikasi sangat menuntungkan bagi negara yang memilikinya. Itu disebakan karena pengaturan menjadi suatu tameng dalam tujuan sebagai aturan terkait berkomunukasi, sebagaimana Upaya untuk menghadirkan suatu perangkat hukum yang sesuai dengan perkembangan dunia informasi dan telekomunikasi menjadi suatu yang tidak bisa ditawar-tawar lagi. Lahirnya UU Tentang ITE yang telah mengalami perkembangan dan saat ini menjadi Undang -Undang Nomor 19 Tahun 2016 Tentang perubahan atas Undang -Undang No. 11 Tahun 2008 tentang ITE Pengaturan yang secara khusus mengatur tentang permaslahan Pornografi dengan proses menggunakan instrumen teknologi.

\section{Pertanggungjawaban Pidana Pelaku Penyebaran Konten Pornogafi Melalui Sarana Internet Yang Dikualifikasikan Sebagai Cyber Crime}

Pada KUHP merujuk pada pasal 282 KUHP tentang transaksi pornografi Sesuai bunyi pasal tersebut beberapa ketentuan sanksi disebut kan sesuai dengan bentuk perbuatan dari kejahatan 
yang pelaku lakukan terhadap korbanya. Dan Menurut UU Pornografi. Di dalam UU ini selain menjabarkan tentang transaksi atau jualbeli saja tapi terdapat larangan dan membatasi hal lain juga yang berkaitan terhadap tindak pidana transaksi pornografi, misalnya saja mendownload, mempertontonkan, penyebarluasan dan lain sebagainya. Larangan membuat pornografi sebenarnya berlaku atas seluruh muatan pornografi yang sebagaimana diatur dalam Pasal 4 Ayat (1), baik pelakunya dalam ikatan perkawinan ataupun tidak. Perbuatan membuat video bermuatan pornografi tersebut kemudian disebarluaskan ke intenet dan di konsumsi oleh masyarakat sehingga menjadi bumerang, yang antara lain dapat menyebabkan (Neng, 2011).

1. Perkosaan;

2. Kekerasan seksual;

3. Perzinaan sesuai pandangan masyarakat;

4. Dalam beberapa bulan kemudian dimungkinkan terjadi aborsi hamil akibat zina yang diakibatkan setelah melihat pornografi bersangkutan; atau

5. Akhirnya anak-anak hasil zina yang berakibatkan tidak dapat mempunyai hubungan darah dengan ayah biologisnya

Menurut Undang-Undang Nomor 44 Tahun 2008 Tentang Pornografi ini sanksi-sanksi yang dijatuhkan untuk pelaku terdapat didalam Pasal 29, Pasal 31 dan Pasal 32, akibat kesengajaan pelaku menyebarkan dan memanfaatkan konten bermuatan pornografi sehingga pelaku sama dengan sengaja melakukan penyebaran video atau foto pornografi melalui media internet Pelaku juga dikenai Pasal 31 ini disebabkan dari pelaku yang mngunduh suatu konten pornografi sebelum menyebarkan atau mempergunakanya untuk kepentingan pribadi yang merugikan masyaakat. Bisa jadi para pelaku tidak mengunduh video tersebut tapi dilakukan sendiri bersama pasanganya yang kemudian di simpan dengan perekaman mandiri. Sesuai dengan kajian diatas, pelaku akan membuat video itu sendiri dengan cara melakukannya dengan pasangannya lalu akan direkam, disimpan setelah itu pelaku akan menyebarkannya ke dalam media internet atau ke web yang bermuatan pornografi yang dia miliki dan juga memperjual belikannya video.

Undang-undang ITE mengatur perbuatan yang tegolong tindak pidana dibidang ITE dan teliti terkait sifat juga penyerangan terhadap kejahatan serupa. Tujuan diterbitkanya UU ini merupakan wujud pelindungan masyarakat tehadap kejahatan dalam dunia mayantara dan serta mencegah supaya masyarakat tidak mencoba bergabung kedalam unsur negatif dari dunia elektonik.. UU ITE berisi aturan banyak tindak pidana era modern dan modus baru, yakni dengan menggunakan media elektronik sebagai mana di maksud salah satunya adalah terkait pornografi dengan elektronik sebagai media. Menurut UU ITE pelaku yang melakukan tindak pidana Transaksi Pornografi tersebut akan dikenakan sanksi yang sudah ditentukan di dalam Pasal 45 Ayat 1 tentang Ketentuan Pidana.

Dikenakan sanksi tersebut karena dalam prosesnya pelaku menyebarkan dan memperlihatkan suatu konten secara sengaja di medai elektronik yang tentunya memuat unsur di dalam ketentuan aturan positif tentang pornografi. Arti dan tujuan dari kalimat "pidana penjara terlama 6 tahun dan/atau denda terbanyak satu miliar rupiah adalah pelaku bisa mendapatkan kedua hukuman tersebut bisa juga salah satu dari dua hukuman diatas, nantinya para pelaku akan disesuaikan pada saat beracara di persidangan dan akan mendapatkan sanksi diantara kedua sanksi tersebut diatas atau keduanya secara tegas. Pasal ini dengan sengaja dibuat supaya pelaku tindakan kesusilaan atau pelaku yang telah melakukan tindak pidana transaksi pornografi ini akan merasa jera dan tidak akan mengulangi tindakan yang dengan sengaja dia perbuat itu. Selain itu, undang-undang ini dibuat dengan maksud untuk memberikan perlindungan terhadap orang-orang yang telah menjadi korban dari pelaku yang melakukan pelanggaran kesusilaan pornografi tersebut kepada orang-orang yang ingin menonton video tersebut.

Hukum pidana memiliki tujuan memberikan keamanan dan kesamarataan suatu keadilan bagi masyarakat (Suyanto, 2018). Hukum pidana juga memiliki kontrol suatu perbuatan pidana, karena dalam hukum pidana seseorang yang melakukan kejahatan akan 
dididik dan diberikan sanksi sesuai dengan perbuatan pidana yang telah ia lakukan hal itu agar seseorang yang melakukan tindak pidana itu memiliki perasaan jera untuk tidak berulah untuk kedua kalinya, seiring dengan adanya aturan dalam peraturan perundang-undangan dapat memberikan tekanan terhadap masyarakat yang berniat buruk dan ingin berbuat tindak pidana.

Pertanggungjawaban pidana pada hakikat nya mengandung makna pencelaan pembuat atas tindak pidana yang telah dilakukannya. Oleh karena itu, pertanggungjawaban pidana mengandung di dalamnya pencelaan objektif dan pencelaan subjektif. Artinya, secara objektif si pembuat sudah berbuat tindak pidana dan secara subjektif si pembuat patut dipertanggungjawabkan atas tindak pidana yang dilakukannya itu sehingga ia patut di pidana. Pertanggungjawban dalam Perundang - undangan yaitu pada KUHP tidak mencantumkan secara tegas apa yang di maksud dengan pertanggungjawaban pidana tetapi pertanggung jawaban pidana diatur secara negatif yang biasanya menggunakan frasa "tidak dipidana" (Pasal 48, 49, 50, 51 KUHP), “ tidak dapat dipertaanggungjawabkan" ( Pasal 44 ayat (1) dan (2) KUHP) dan lain lain. Dalam KUHP prihal transaksi pornografi diatur di dalam pasal 282 ayat (1) mengenai kejahatan kesusilaan yg memenuhi unsur cyberporn atau cyber pornografi. Terkait dengan perundang - undangan yang berlaku prihal transaksi pornografi ini jelas di sebutkan secara komplek dalam ketentuan pasal 4 UU Pornografi. Apabila di tinjau dari UU ITE di indonesai akan menjurus ke unsur-unsur yang terkandung dalam setiap pasal terkait transaksi pornografi atau cyber pornografi sesuai UU ITE.

\section{KESIMPULAN DAN SARAN}

\section{Kesimpulan}

Dari pemaparan hasil penelitian diatas dapat disimpulkan sebagai berikut:

1. Pengaturan hukum terhadap pelaku tindak pidana penyebaran konten pornografi melalui sarana internet yang di kualifikasikan sebagai Cybercrime :

a. Menurut KUHP pengaturannya diatur atau masuk ke dalam bab XIV Kejahatan terhadap Kesusilaan pada pasal 282 ayat (1)

b. Menurut UU ITE. apabila memenuhi unsur Pasal 27 ayat (1) akan dapat terkena sanksi pidana yang telah diatur dalam Pasal 45 ayat (1) UU ITE.

c. Menurut UU Ponogafi diatur secara umum pada Pasal 4 Undang - Undang Nomor 44 Tahun 2008 Tentang Pornografi yaitu Pelanggaran pasal 4 ayat (1) UU Pornografi dapat diancam pidana sebagaimana diatur dalam Pasal 29 Undang - Undang Pornografi.

2. Pertanggungjawaban Pidana terhadap pelaku tindak pidana penyebaran konten Pornografi melalui sarana internet yang di kualifikasikan sebagai Cybercrime :

a. Pertaggungjwaban pidana menurut KUHP yaitu dapat diancam dengan pidana penjara paling lama satu tahun enam bulan atau pidana denda paling tinggi empat ribu lima ratus rupiah.

b. Pertaggungjwaban pidana menurut Undang-Undang Nomor 19 Tahun 2016 Tentang Perubahan Atas Undang-Undang Nomor 11 Tahun 2008 Tentang Informasi dan Transaksi Elektronik yaitu Setiap Orang yang memenuhi unsur sebagaimana dimaksud dalam Pasal 27 ayat (1), dipidana dengan pidana penjara paling lama 6 (enam) tahun dan/atau denda paling banyak satu miliar rupiah.

c. Pertaggungjwaban pidana menurut Undang - Undang nomor 44 tahun 2008 tentang Ponogafi yaitu Setiap orang pelaku dapat dipidana dengan pidana penjara paling singkat 6 (enam) bulan dan paling lama 12 (dua belas) tahun dan/atau pidana denda paling sedikit Rp 250 juta dan paling banyak 6 miliar.

\section{Saran}

Berdasarkan simpulan diatas, penulis memberikan pandangannya terhadap makin meningkatnya perbuatan penyebaran konten pornografi melalui internet, berikut ini penulis memberikan berupa saran dan masukan kepada beberapa pihak, diantaranya: 
1. Seharusnya Pemerintah melalui Kominfo melakukan pemblokiran situs di Internet. Mulai dari situs dengan konten pornografi, pornoaksi hingga yang terbaru situs streaming film illegal, sehingga tidak ada lagi akses yang bisa dibuka kalangan anak sekolah apalagi di zaman pandemi covid 19 ini, sekolah dirumah, dimana orangtua tidak bisa memantau sepenuhnya anak-anaknya. Serta mempermudah proses pelaporan dan penindakan terhadapat situs atau website yang melanggar norma kesusilaan. Untuk menutup akses penyebaran konten penyebaran pornografi di internet yang di kualifikasikan sebagai cybecrime.

2. Bagi masyarakat yang secara tidak sengaja menemukan situs atau website yang mengandung unsur pornografi atau melanggar norma kesuliaan dapat melakukan pengaduan ke pemerintah melalui kominfo dan intansi terkait. Agar dapat segera di tindak lanjuti sehingga dapat meminimalisir penyebaran konten pornografi yang di kualifikasikan sebagai cybecrime. Untuk bersama mengawal internet positif atau sehat bagi masyarakat sendiri dan juga generasi penerus bangsa.

3. Bagi orang tua agar bisa memberikan edukasi kepada anak - anak nya generasi muda kita terkait bagaimanakah berbahayanya konten pornografi apabila di konsumsi terhadap umur yang belum dewasa. Sehingga nantinya generasi kedepan lebih paham apabila secara tidak sengaja mengakses dan menemukan konten pornografi di internet yang di kualifikasikan sebagai cybecrime.

\section{DAFTAR PUSTAKA}

Atmadja, I. D. G., \& Budiartha, I. N. P. (2018). Teori-teori hukum. Setara Press, Malang

Chazawi, A. (2016). Malapraktik Kedokteran. Sinar Grafika, Jakarta.

Djanggih, H. (2013). Kebijakan Hukum Pidana Dalam Penanggulangan Tindak Pidana Cyber Crime di Bidang Kesusilaan. Jurnal Media Hukum, Vol.1(2).

Geni, N. P. L., Sahari, A., \& Fauzi, A. (2020). Kebijakan Kriminal Pertanggungjawaban Pidana Terhadap Anak Korban Konten Pornografi. Journal Sociaty Law, Vol.1(1).

Mudzakkir. (2010). Analisis atas Mekanisme Penanganan Hukum terhadap Tindak Pidana Kesusilaan. Kementerian Hukum dan HAM RI Badan Pembinaan Hukum Nasional.

Maskun. (2013). Kejahatan Siber (Cyber Crime). Kencana Prenada Media Group, Jakarta.

Nadia, C. S., \& Mahfud. (2018). Pertanggungjawaban Pidana Terhadap Pelaku Penyalahgunaan

Aplikasi Streaming "Bigo Live" Dalam Konten Pornografi. Jurnal Ilmiah Mahasiswa:Bidang Hukum Pidana, Vol.2(4).

Neng, D. (2011). Perzinaan Dalam Peraturan Perundang-Undangan di Indonesia Ditinjau dari Hukum Islam. Kencana Pranada Media Group, Jakarta.

Suyanto. (2018). Pengantar Hukum Pidana (Cet.1). Deepublish, Yogyakarta.

Wirawan, N. (2013). Pertanggungjawaban Pidana Terhadap Penayangan Pornografi Dalam Dunia Maya Menurut UU No. 44 Tahun 2008 Tentang Pornografi. Fakultas Hukum, Universitas Hasanuddin. 